Studia Anglica Posnaniensia 46/1, 2010

doi: 10.2478/v10121-009-0029-y

\title{
TELLING IT STRAIGHT: A COMPARISON OF SELECTED ENGLISH AND POLISH IDIOMS FROM THE SEMANTIC FIELD OF SPEAKING
}

\author{
RENATA SZCZEPANIAK - ARLETA ADAMSKA-SAŁACIAK
}

Adam Mickiewicz University, Poznań

\begin{abstract}
This paper attempts to illustrate one way of achieving greater precision in presenting idiomatic equivalents by implementing the functionally-oriented methodological instrument devised by Dobrovol'skij and Piirainen (2005). A small-scale analysis along the three parameters of semantics, syntax and pragmatics is carried out with a view to identifying and explaining all cross-linguistic contrasts and similarities between selected English and Polish near-equivalent idioms from the semantic field of speaking. The empirical data of this study includes corpus evidence, apart from the available monolingual, bilingual and phraseological dictionaries. The resultant descriptions of the idiomatic expressions attest the validity of a functional approach to contrastive idiom analysis, which, unlike judgments based on the superficial properties of idioms (i.e. their lexical components, structure), reveals that differences in images will not always prevent idioms with similar actual meaning from being regarded as equivalents. On the other hand, closeness of underlying imagery does not guarantee identity with respect to all parameters of comparison (especially pragmatics).
\end{abstract}

\section{Introduction}

The important question of bilingual lexicography: whether to give a verbatim translation of a source language (SL) phraseological unit or always aim at a target language (TL) phraseological unit of the same kind as the SL item, does not have an agreed upon answer. Zgusta (1971: 339) argues for the former solution in the case of proverbs, allowing for the latter only if the TL proverb itself "is absolutely clear (preferably less metaphorical than that of the source language) and really well known". Svensén (1987 [1993]: 156) definitely favours the latter option: "[i]dioms in the source language must as far as possible be paralled in the target language by idioms with the same content". Talking of fixed expressions in general, Roberts (1996: 193) recommends 
idiomatic translations whenever possible; only in cases where an idiomatic equivalent is clearly lacking is she willing to accept a literal translation. On the whole, the general preference for idiomatic equivalents seems clear.

So far, the issue of phraseological equivalence has not been given due attention in bilingual lexicography. ${ }^{1}$ As Farø (2007: 84) points out, bilingual lexicographers base their judgments, more often than not, on the most superficial properties of idioms, i.e. their lexical components, structure, imagery: "Idiome lösen bei Linguisten, darunter auch Lexikographen, häufig eine Art 'Bilderfetischismus' aus. In der bilingualen Lexikographie wird nicht selten mehr Wert auf Bilder als auf den Sprachgebrauch gelegt. [Idioms often evoke in linguists, among them lexicographers, a kind of "image fetishism". In bilingual lexicography, more emphasis is put on images than on language use.]". This tendency, termed by Farø (2007: 84) "der Drang des Lexikographen nach einer Art 'Bilderharmonie' [the lexicographer's urge for a sort of "image harmony"]", does not serve the communicative needs of dictionary users well and should give way to a more functional approach, based on investigating idiom properties in context (Dobrovol'skij - Piirainen 2005; Farø 2007).

This paper attempts to illustrate one way of achieving greater precision in presenting idiomatic equivalents by implementing the functionally-oriented methodological instrument devised by Dobrovol'skij and Piirainen (2005), proponents of the so-called Conventional Figurative Language Theory, which differs from the better-known Cognitive Metaphor Theory (CMT) in terms of its goals:

\begin{abstract}
For the CMT, it is important to discover quasi-universal conceptual metaphors that underlie each single metaphorical expression ... For the Conventional Figurative Language Theory, however, the level of the very general metaphor is mostly of no interest. The Conventional Figurative Language Theory has to explain how the characteristics of figurativeness (above all, the image component) influence semantic and pragmatic specifics of CFUs [conventional figurative units]
\end{abstract}

(Dobrovol'skij - Piirainen 2005: 130).

In the following, the Conventional Figurative Language Theory will be combined with those basic elements of the CMT to which Dobrovol'skij and Piirainen (2005) themselves make frequent reference.

\title{
2. Sources and types of idiom equivalence
}

The idiomatic content plane is built of two elements: the actual meaning and the mental image. The fact that these are relatively independent of each other re-

For a recent extensive coverage of the treatment of phraseological units in lexicography, see Mellado Blanco (2009). 
sults, as Dobrovol'skij and Piirainen (2005: 68) put it, in "the existence of idioms which have (nearly) the same image, but differ with regard to their actual meanings, as well as the existence of idioms which have (nearly) the same actual meaning, but differ with regard to their images. Hence, these two major types of non-equivalence and their different combinations can be distinguished". Establishing whether two idioms are equivalent (either within one language or cross-linguistically) requires a systematic comparison between their respective actual (i.e. figurative) meanings and underlying images (literal readings). The possible configurations of differences constitute the semantic parameter of idiom equivalence, the other two dimensions being the syntactic and the pragmatic parameter. Whereas specific contrasts in the semantic, pragmatic or syntactic behaviour of idioms often go back to individual images, the cognitive linguistic instrument of conceptual metaphor accounts for the underlying similarity of superficially distinct idioms (Dobrovol'skij - Piirainen 2005: 61).

Contrastive analysis of the three dimensions aims at discovering functional equivalents, that is "lexical items of both source and target language (L1 and L2) which can be used in the same situations" (Dobrovol'skij - Piirainen 2005: 56). For obvious reasons, bilingual dictionaries cannot predict all instances of idiom use, or, by the same token, list all contextual equivalents: lexicographic equivalents are rarely translational equivalents. ${ }^{2}$ The ultimate selection of the former would be constrained not only by lexicological analysis, but also by dictionary functions (e.g. reception, production) and target users (L1 or L2 speakers) (Farø 2007). Therefore, a major advantage of a fine-grained functionallyoriented analysis for lexicographers is not a list of functional equivalents, but a precise profile of an idiom's semantic, syntactic and pragmatic behaviour, which can in turn facilitate the identification of differences between nearequivalents and the consequent informed choice of the best candidate(s) for lexicographic equivalents. A functional analysis using the three parameters is recommended as practically and theoretically sounder than the traditional phraseological description in terms of full, partial, and non-equivalents (see Dobrovol'skij - Piirainen [2005: 61-62] for a critique of this categorization). The ensuing section attempts to apply the guidelines for functional contrastive idiom analysis, the results of which may serve as a database assisting the selection of phraseological equivalents by bilingual lexicographers (as well as translators).

2 See Adamska-Sałaciak (2006: 99-106) for a detailed discussion of these types of equivalence. 


\section{Analysis}

The departure point of our analysis is an example of a common situation where one L1 idiom is translated by several L2 idioms (and vice versa), often within the same dictionary. In this case, we are faced with a chain of alleged equivalents denoting a forthright manner of speaking:

NKFD wyktadać kawę na tawę - 'not mince words, say openly'

$P W N O P$ kawa na tawe - 'without mincing words $a$. beating about the bush'

NKFD not mince (one's) words - 'nie przebierać w słowach'

$P W N O P$ nie przebierać $w$ stowach - 'to not mince one's words'

NKFD beat about/around the bush - 'owijać w bawełnę'

A more precise discrimination between quasi-synonymous idioms would certainly benefit bilingual dictionary users. In what follows, five idioms denoting an open manner of speaking will be examined as potential candidates for equivalence: two for English (not mince words, not beat about the bush) and three for Polish (wyktadać kawe na ławę, nie przebierać w stowach, nie owijać w bawetnę).

\section{1. not mince (one's) words (variant: without mincing words)}

\subsubsection{Semantics}

actual meaning: ${ }^{3}$

to use direct, forceful words when speaking your mind, to say what you mean without trying to be polite

The positive form, mince (one's) words is not an exact antonym, as it includes a pejorative component, which surfaces in the following examples:

1) She found herself irritated by the interviewer's mincing (=too delicate and not direct enough) way of asking questions

$(C I D E)$.

2) In a very real sense, then, the Big Bang Universe has existed forever. Some scientists -; and we should add hastily that they are in a small minority -; feel that this is mincing words: they feel that by "forever" we should mean an infinite number of billions of years rather than a period whose duration can be estimated

$\left(\mathrm{BYU}-\mathrm{BNC}^{4}\right)$.

The actual meanings we postulate for all analysed idioms have been synthesised from the dictionaries cited in the References. http://corpus.byu.edu/bnc 
mental image:

Holt (1961) relates mince to Latin minutia 'smallness, fineness', offering the analogy with the mincing of meat as a motivating link: "'He didn't mince matters' means 'He spoke out frankly'; i.e., it was not hash that his hearers had to swallow, but tough beefsteak". This idea is repeated in Brewer: "[f]rom the mincing of meat to make it more digestible or pleasing". Apparently, the image is that of words (which contain ideas) ${ }^{5}$ being cut into small pieces so that they can be received without discomfort. "Unminced" words are gross and indigestible. The secondary meaning of the adjective indigestible ("not easy to understand') constitutes part of the linguistic evidence for the metaphor IDEAS ARE FOOD, with its submappings: ACCEPTING IS SWALLOWING and UNDERSTANDING IS DIGESTING (Kövecses 2002: 72-74). The mental image highlights the manner of serving the "food" (words/ideas).

\subsubsection{Syntax}

The idiom adopts two major patterns:

$[\mathrm{Neg}($ not $)+\mathrm{V}($ mince $)+(\mathrm{det})($ one's $) \mathrm{N}($ words $)]$ or

[prep (without) + gerund (mincing) $+\mathrm{N}($ words $)]$.

Typically, it takes a human subject:

3) The doctors didn't mince their words, and predicted the worst

(COBUILD2).

Less frequently, there occur non-human subjects:

4) The report does not mince words about the incompetence of some government officials

$(C I D E)$.

5 In accordance with Reddy's (1979) Conduit Metaphor, (i) THE MIND IS A CONTAINER (FOR IDEAS), (ii) IDEAS (OR MEANINGS) ARE OBJECTS, (iii) COMMUNICATION IS SENDING, (iv) LINGUISTIC EXPRESSIONS ARE CONTAINERS (FOR IDEASOBJECTS) (Krzeszowski 1997: 170). As further noted by Krzeszowski (1997: 174), component (iv) of this conceptual metaphor "can also be instantiated by more specific source domains since ... containers may be of various kinds. There are numerous linguistic expressions coherent with such instantiations. Thus, words can be 'soft' or 'hard', 'light' or 'heavy', 'delicate' or 'rough', 'sharp' or 'blunt', 'heated/hot' or 'cold/cool'. They can be 'cracked' (like nuts), 'coined' (like medals), 'distorted' (like practically anything), 'minced' (like meat), 'borrowed', though practically never returned, 'played on' (like musical instruments), 'broken' (like fragile objects), and 'weighed"'. 
5) Auto Express did not mince its words: "It's difficult to see how much more Ford could have done to improve a car that was already very good"

(BYU-BNC).

6) The introductory leaflet did not mince its words: "It was a period when words contradicted deeds, propaganda realities, and when everyday life was full of fear, hypocrisy, and people felt helpless, having been at the mercy of those in power"

(BYU-BNC).

\subsubsection{Pragmatics}

degree of familiarity and/or textual frequency:

The expression appears to be commonly known; it is marked as a key idiom in CCID2. The corpus search yielded 37 concordances.

illocutionary function:

Two broad discourse functions of the idiom not mince (one's) words emerge. First, it acts metalinguistically, preparing the addressee for the harsh words they are about to hear (occasionally with an implied negative assessment of whoever utters them):

7) Never one to mince words, Carlie told her daughter that her looks were fading

(COBUILD2).

8) He's a brash New Yorker who doesn't mince his words (LDOCE3).

9) They did not mince their words. One developer said his speech was "as welcome as a bad smell in a space capsule" (BYU-BNC).

10) "Believe me, your cousin doesn't mince her words", he added ruefully

(BYU-BNC).

Secondly, mincing one's words is generally regarded as undesirable:

11) You don't have to mince your words for my benefit, Harry (BYU-BNC).

12) Can you promise you won't be mincing your words? No way -; we'll tell the truth when it's needed to be told

(BYU-BNC).

13) It is unkind -; perhaps I should not mince words - ; it is cruel to keep albino fish under bright lights; with a fish like the Oscar, often kept in a tank with no shade to escape into, this detail is particularly important

(BYU-BNC). 
3.2. not beat about/around the bush (variant: without beating about/around the bush)

\subsubsection{Semantics}

actual meaning:

It is convenient to start the analysis with the definition of the opposite: beat about the bush 'approach a matter cautiously, indirectly, even over-cautiously or circuitously, because it is unpleasant, embarrassing, or delicate' (Brewer, CIDE, LDOCE3). Not beat about the bush is the exact antonym: 'approach a matter directly and immediately, without unnecessary delay, get to the point quickly'.

mental image:

The expression is believed to have originated in hunting: "one goes carefully when beating a bush to find if any game is lurking within" (Brewer). In an attempt to explain the origin of the phrase, Holt (1961: 19) suggests that "the notion of going around the bush rather than plunging to the heart of it would seem to apply less well to the beaters, who make enough noise to scare the average fox from a good distance away, than to a hesitating hound". The image of carefully circling a bush in search of game corresponds to the cautious manner of approaching the subject as if it were a dangerous or skittish animal. The opposite, not beating about the bush, evokes the image of not bothering to be very careful in approaching the game (or the subject of conversation).

\subsubsection{Syntax}

The idiom is sometimes preceded by (there is) no point in... (5 times out of 35 in the BNC). Two major patterns are attested:

$[\mathrm{Neg}($ not $)+\mathrm{V}($ beat $)+\operatorname{prep~(about)} \mathrm{NP}($ the bush)] or [prep (without) + gerund (beating) + prep (about) NP (the bush)].

The expression typically takes a human subject:

14) I mean, let's not beat about the bush here ...

(BYU-BNC).

15) I won't beat about the bush about creeping privatisation because ...

(BYU-BNC). 
In the version without not, it is often preceded by other elements of negation:

16) He never beat about the bush when something was annoying him

17) Seeing no point in beating about the bush, she spoke directly

(BYU-BNC).

(BYU-BNC).

The positive form, although less frequent, is by no means rare:

18) ... well we could beat about the bush but ...

(BYU-BNC).

19) She winced at their infelicities, at the clumsy way they beat about the bush

(BYU-BNC).

\subsubsection{Pragmatics}

stylistic properties:

The idiom can be encountered in informal as well as formal contexts. Examples of the former include:

20) ... and let's not beat about the bush, "drop the dead f*****g donkey" and play Wallace and Forrester up front

(BYU-BNC).

21) You know, the one that gets on your nerves! Not very nice! Well Well she was! Not worth beating around the bush is there? Well are there single rooms there or Yeah! they're single, the accommodation is single then is it?

(BYU-BNC).

In formal contexts, the expression seems to stand out and, as such, is sometimes marked graphically by inverted commas. The use of the familiar idiom presumably serves to make a difficult message more accessible:

22) The reason that Jesus talked with this woman was that he wanted to save her. That is, to say, he wanted to reveal to her, her sinful condition and need, and this he did when he speaks to her, about her sinful life. He doesn't beat about the bush. He doesn't come soft with it (BYU-BNC).

23) That is to say, the important international conference to take place at Darlington Hall was by then looming ahead of us, leaving little room for indulgence or "beating about the bush"

(BYU-BNC).

degree of familiarity and/or textual frequency: 
The BNC total frequency is 35 (per 100 million words), that is, similar to that of not mince (one's) words.

cultural component:

The background knowledge pertains to hunting customs, in particular to the fact that the hunter was required to walk carefully around any vegetation suspected of hiding a fox or a game bird.

illocutionary function:

The idiom functions as a veiled comment on people's verbal behaviour. While beating about the bush tends to be condemned, the opposite is praised as a token of the speaker's openness and directness:

24) She winced at their infelicities, at the clumsy way they beat about the bush. She saw that it had been a mistake -; an evasion perhaps? -; to hamper herself with the abstractions of that cryptic poem (BYU-BNC).

25) He was often charming, sometimes rude, but always straight. He never beat about the bush when something was annoying him, he was never afraid to give it to you straight, to say exactly what he thought

(BYU-BNC).

26) Let me come straight to the point. I am not a person to beat about the bush. I like to say what I have to say in as few words as possible and to lay my cards on the table for all to see

(BYU-BNC).

\section{3. nie przebierać $w$ stowach}

\subsubsection{Semantics}

actual meaning:

to use direct, forceful, often crude or vulgar words when speaking your mind, to say what you mean without trying to be polite

The use of crude words is foregrounded in all dictionary definitions; in the examples found in the National Corpus of Polish, ${ }^{6}$ words of this kind often feature in the co-text:

$6 \quad$ http://www.NKJP.pl 
27) Do du... z taką demokracją - nie przebiera $w$ stowach 46-letni Kazimierz Świdroń.

[Sod such democracy - 46-year-old Kazimierz Świdroń “doesn’t pick and choose words".]

28) ... [S]ąsiadka przystępuje do ataku. Nie przebiera $w$ słowach. Wyzywa mnie od najgorszych i wciąż grozi...

$[\ldots[T]$ he neighbour launches an attack. She "doesn't pick and choose words". She calls me names and keeps threatening me...]

29) Draństwo i szczyt głupoty - Kamil Rogowski nie przebiera $w$ stowach. [Villainy and the extreme of stupidity - Kamil Rogowski "doesn't pick and choose words".]

30) ... [T] e ekonomiczny rasizm ze strony Szczecina - nie przebiera $w$ stowach Grabowski.

$[\ldots[\mathrm{T}]$ his is economic racism on the part of Szczecin - Grabowski "doesn't pick and choose words".]

31) Andrzej nie przebierat $w$ stowach, ciskał obelgami...

[Andrew "did not pick and choose words", he hurled insults...]

mental image:

The verb przebierać is defined in SJP online as follows:

1. oczyścić coś, wybierając to, co właściwe, a odrzucając to, co uszkodzone, zepsute

[clean something, choosing what is appropriate, and rejecting what is damaged, rotten]

2. nie móc się zdecydować na coś, rzadziej na kogoś

[be unable to deCIDE on sth, rarely on sb]

SSJP further specifies the latter meaning as wybredzać, grymasic 'be choosy, fussy'. The verb przebierać is also encountered in expressions such as przebierać jak $w$ ulegatkach lit. 'sort sth like wild pears', meaning 'pick and choose'; nie przebierać $w$ środkach 'do sth by fair means or foul'. Accordingly, the emerging image of the idiom under analysis is that of someone not caring to separate the good objects (words) from the bad. If one is not "choosy" about words, one does not care whether they are appropriate or polite.

\subsubsection{Syntax}

The idiom nie przebierać $w$ stowach $[\mathrm{Neg}($ not $)+\mathrm{V}$ (pick and choose $)+$ prep (in) $+\mathrm{N}^{\mathrm{loc}}($ words $\left.)\right]$ typically takes a human subject, which is sometimes ex- 
pressed by a collective noun, such as zaloga 'crew' or opozycja 'the opposition'. The verb component can take the present participle form, e.g.:

32) ... choć pismo nie przebierajac $w$ stowach atakuje i Cimoszewicza, i także jego samego (NKJP). [... although the magazine, "not picking and choosing words", criticizes both Cimoszewicz and himself.]

There are also examples of the adjectivised expression [Neg (not) + Adj (picking-and-choosing) + prep (in) $+\mathrm{N}^{\text {loc }}$ (words)] modifying a nonhuman subject such as polemika 'polemics', debata 'debate', atak 'attack' or krytyka 'criticism', e.g.:

33) ... [O]bok dawnej, często totalnej i nie przebierajacej $w$ stowach krytyki, dostrzeżemy również elementy...

$(N K J P)$.

[... [S]ide by side with the old, often total and "not-picking-andchoosing-words" criticism, we can also discern elements of...]

34) Inną specjalnością pisma były ostre, nie przebierajace $w$ stowach polemiki

(NKJP).

[The magazine also specialized in fierce, "not-picking-and-choosingwords" polemics.]

35) On pierwszy naraził się na nie przebierajace $w$ stowach i ocenach ataki "prawdziwych Polaków"

$(N K J P)$.

[He was the first to be subjected to the "not-picking-and-choosing" attacks of "true Poles".]

The idiom is only occasionally used without the negative:

36) ... sympatyczny, przyjemny, łagodny. Mówi najwyraźniej przebierajac $w$ stowach, jest cukierkowaty

(NKJP).

[... likeable, pleasant, gentle. He evidently speaks "picking and choosing" his words, he is sugary.]

Przebierać $w$ stowach is not a simple antonym of the canonical form. It means: 'to use excessively mild terms to express your opinion', rather than 'not to use rude words when expressing your opinion'.

\subsubsection{Pragmatics}

stylistic properties: 
The dictionaries are silent on this point. In the corpus, the idiom is found in both informal and formal contexts.

degree of familiarity and /or textual frequency:

The idiom is commonly known. It appears 146 times per 350 million words.

illocutionary function:

The expression is used to prepare the addressee for the unpleasant words which are about to follow. It can also act as a (negative) metalinguistic comment on someone's way of speaking.

\section{4. nie owijać w bawetnę (variant: bez owijania w bawetnę)}

\subsubsection{Semantics}

actual meaning:

to speak or write about something openly, without using euphemisms, e.g.:

37) Mówi prosto, dosadnie, nie owija w bawetnę...

$(N K J P)$. [He speaks simply, bluntly, doesn't "wrap it in cotton"...]

38) Jak coś mi leży na wątrobie, to mówię. Na ogół nie owijam w bawetnę. W związku z tym mam dużo wrogów $(N K J P)$. [When something bothers me, I speak out. I do not normally "wrap it in cotton". As a result, I have many enemies.]

39) Nie ma co owijać w bawetne - chciałem uciekać [No use "wrapping it in cotton" - I wanted to run.]

$(N K J P)$.

40) Potrafi dotrzeć do piłkarza w prosty sposób. Nie używa skomplikowanych określeń, nie owija w bawetnę. Po chłopsku mówi, o co mu chodzi

$(N K J P)$.

[He can get through to the footballer in a straightforward manner. He doesn't use sophisticated expressions, he doesn't "wrap it in cotton". He speaks his mind like a peasant.]

The truth being told is usually difficult and/or unpleasant, e.g.:

41) Dąbrowski patrzy smutnej prawdzie prosto $\mathrm{w}$ oczy i nie owijajac $w$ bawetnę mówi: - Nie myślałem, że będzie aż tak źle

(NKJP).

[Dąbrowski faces the sad truth and says without "wrapping it in cotton" I did not expect it to be that bad.]

42) Nie ma co owijać w bawetnę. Spisujemy się słabo...

$(N K J P)$.

[No point in "wrapping it in cotton". We are doing poorly...] 
mental image:

As Professor Długosz-Kurczabowa explains, "[t]en obraz wychodzącej z nasienia, rozwijającej się bawełny stał się podstawą znaczeń przenośnych tego wyrazu [bawetna] [[t]he image of the burgeoning white fluff coming out of the cotton seed forms the basis for metaphorical meanings of this word [cotton]]". Thus, the idiom's underlying image is that of wrapping something in the threads of the cotton plant. Even if the surface of the object is rough, the layer of white cotton makes it look soft, deceitfully safe and innocent: cotton hides the real nature of the thing it envelops. Here it is, of course, the objectified hard words that are (not supposed to be) wrapped in cotton. The motivating metaphor seems to be KNOWING IS SEEING (Kövecses 2002: 59).

\subsubsection{Syntax}

The idiom bez owijania $w$ bawetne is frequently accompanied by nie będe... 'I'm not going to...', nie ma co... 'there is no point in...'. It often combines with mówic' 'speak'. Adverbials of manner such as szczerze 'sincerely', otwarcie 'openly', uczciwie 'honestly' are frequently found in the immediate co-text, echoing and reinforcing the meaning of the phrase.

The idiom occurs both in the negative and positive form. The latter, less frequent, has the meaning 'express yourself indirectly, use euphemisms'. The Agent is always human. The following patterns are attested:

nie owijać (czegoś) w bawetne $\left[\mathrm{Neg}(\right.$ not $)+\mathrm{V}($ wrap $)($ sth $)+$ prep $($ in $)+\mathrm{N}^{\mathrm{acc}}$ (cotton)];

(mówić) nie owijajac $w$ bawelne $[(\mathrm{V})($ speak $)+\mathrm{Neg}($ not $)+$ PresParticiple (wrapping) + prep (in) $+\mathrm{N}^{\text {acc }}($ cotton $\left.)\right]$

(mówić) bez owijania w bawetne $\left[(\mathrm{V})(\right.$ speak $)+\operatorname{prep~(without)~}+\mathrm{N}^{\text {gen }}$ (wrapping $)+\operatorname{prep}($ in $)+\mathrm{N}^{\mathrm{acc}}($ cotton $\left.)\right]$.

In the corpus there are only two examples of the idiom without negation:

43) Pisałem, naturalnie, bardzo ostrożnie, owijajac w bawetne [I wrote very carefully, of course, "wrapping it in cotton".]

$(N K J P)$.

44) Przez długi czas wszelkie nasze zabiegi kampanijno-prewencyjne odwoływały się do aluzji i "owijania w bawetnę". Ich przesłanie było słabo czytelne, zwłaszcza dla młodzieży

$(N K J P)$.

\footnotetext{
7 PWN online information service: http://poradnia.pwn.pl/lista.php?szukaj=bez+ogr\% F3dekandkat $=18$.
} 
[For a long time all our campaigning-preventive efforts relied on allusion and "wrapping it in cotton". Their message was unclear, especially to young people.]

There is also a maximally reduced nominalised form, the relatively new (and infrequent) creation:

$$
\text { bez bawetny [prep (without) } \left.+\mathrm{N}^{\text {gen }}(\text { cotton })\right]
$$

\subsubsection{Pragmatics}

stylistic properties:

The expression is definitely informal, although none of the consulted dictionaries labels it as such.

degree of familiarity and/or textual frequency:

The idiom is commonly known. The corpus search yields 182 hits (per 350 million words).

cultural component:

The knowledge involved is that of cotton growing on plantations, especially the appearance of cotton seeds surrounded by soft white threads, with their connotations of delicacy and innocence.

illocutionary function:

Historical sources, as quoted by Professor Długosz-Kurczabowa, ${ }^{8}$ indicate that "wrapping (sth) in cotton" was strongly condemned:

Rzetelny obwijać prawdy w bawełnę nie lubi. (Monitor) [A reliable person does not like to "wrap truth in cotton." (Monitor)]

Gorszy niźli padalec, wąż, jaszczur i żmija, człowiek, co skargę, chwały bawełną obwija (W. Potocki) [A man who wraps his complaint in the cotton of glory is worse than a blindworm, a snake, a lizard or a viper. (W. Potocki)]

"Wrapping (sth) in cotton" is synonymous with being devious, and the behaviour in question is generally disapproved of, as evidenced by the frequent occur-

8 PWN online information sernice: http://poradnia.pwn.pl/lista.php?szukaj=bez+ogr\% F3dekandkat $=18$ 
rence of the negative imperative Don't "wrap (it) in cotton". Speaking "without cotton", on the other hand, is assumed to characterise a straightforward, honest person:

45) ... [J]est człowiekiem prostolinijnym, nie kluczy, nie owija $w$ bawetne tego, co ma do powiedzenia

$(N K J P)$.

$[\ldots[\mathrm{H}] \mathrm{e}$ is a straightforward man, he does not hedge, does not "wrap in cotton" what he has to say.]

46) ... [N]ie boi się mówić wprost, gdy coś mu się nie podoba, nie owija niczego w bawetnę, tylko przedstawia swój punkt widzenia $\quad(N K J P)$. $[\ldots[\mathrm{H}] \mathrm{e}$ is not afraid to speak out when he doesn't like something, he does not "wrap anything in cotton" but presents his point of view.]

47) Przynajmniej szczerze i bez owijania $w$ bawetnę ustępujący premier wythumaczył,... [At least the outgoing Prime Minister explained honestly and without "wrapping it in cotton", ...]

As a rule, this way of telling the truth is appreciated:

48) Potrzebujemy kogoś, kto powiedziałby nam brutalnie, bez owijania $w$ bawetnę kilka ważnych prawd o naszym stanie zdrowia (NKJP).

[We need someone who would tell us with brutal honesty, "without wrapping in cotton", a few truths about our state of health.]

49) Jego siła polega na tym, że nie owijajac w bawetnę, mówi ludziom o tym, co ich naprawdę interesuje i boli...

(NKJP).

[His strength lies in his "not wrapping it in cotton"; he talks to people about what they are really interested in and concerned about ...]

Still, isolated contexts can be found when such an open way of speaking is evaluated negatively:

50) ... [Z]awsze rąbał swoją prawdę nietaktownie, bez owijania w bawetnę

$(N K J P)$

$[\ldots[\mathrm{H}] \mathrm{e}$ would always give it straight, tactlessly, without "wrapping it in cotton".]

3.5. wykładać kawę na tawe (variant: kawa na ławę)

\subsubsection{Semantics}

actual meaning: 
Two senses of this Polish idiom can be distinguished: (a) to explain something in simple terms, in a way that is easy for someone to understand; (b) to speak openly or directly, bluntly; to say what you mean clearly and directly, even if this upsets someone. This polysemy is reflected in the following examples:

a):

51) Widzę, że sobie $\mathrm{z}$ tym zadaniem nie radzisz, więc siadaj, wytłumaczę ci kawa na ławe, jak się rozwiązuje takie równania (WSFJP). [I can see you can't handle this maths problem on your own. Let me explain it to you "coffee on the coffee table" how to solve such equations.]

52) I proszę mi to tak po chłopsku, kawę na ławe, żebym była zdolna zrozumieć to

$(N K J P)$.

[And please, explain it to me "like a peasant", "coffee on the coffee table", so that I can get it.]

b):

53) Chciałem jednak upewnić się jeszcze w tej sprawie, żeby pan minister to powiedział wprost, wyktadając kawę na tawę...

(NKJP).

[Still, I wanted to make sure that you, sir, tell it straight, "putting coffee on the coffee table"...]

54) Rozmawiałam z mężem szczerze. Wytożyłam kawe na ławę. Wyśmiał mnie (NKJP). [I talked to my husband honestly. I "put coffee on the coffee table". He laughed at me.]

Sense (b) combines directness with forcefulness and lack of regard for other people's feelings:

55) Bonifacy wyłożył swoje pouczenia brutalnie, kawa na ławe (NKJP). [Bonifacy gave his admonitions with brutal honesty, "coffee on the coffee table".]

56) Prezes był bardzo dyplomatyczny w stwierdzeniach, ale "kawę na ławę" wyłożyt członek zarządu klubu Andrzej Hara

$($ NKJP $)$. [The president was very diplomatic in his statements, but the member of the board of directors, Andrzej Hara, "put coffee on the coffee table".]

9 The Polish idiom po chtopsku 'like a peasant, in a simple manner, so that even an unintelligent person can understand', exploits the connotations of one of the senses of chtop 'peasant', stereotyped as an obtuse simpleton. 
mental image:

The Polish idiom may evoke the image of a cup of coffee being placed on the coffee table. Typically, this act is a prelude to a conversation, a friendly chat, in which people can explain things, speak openly, without constraints. Hence, the act of placing (a cup of) coffee on the table can metonymically stand for the open speaking that ensues. Alternatively, one can conceive of a merchant laying a bag of coffee grains on the counter for customers who want to examine its quality. Once they have seen the grains, they know whether or not this is good quality coffee. Such an image finds its confirmation in the following creative exploitation of the phrase:

57) ... kiedy Miller, Nabokov, Roth i inni już kilkadziesiąt lat temu wyłożyli kawę na ławę? Ziarnko po ziarnku (NKJP). [... when Miller, Nabokov, Roth and others laid coffee on the coffee table a few dozen years ago? Grain by grain.]

Whichever image is regarded as more plausible, both seem to incorporate the "openness, directness" rather than the "bluntness, forcefulness" element.

\subsubsection{Syntax}

The Agent is always human. The idiom takes on two basic forms:

$\mathrm{V}$ kawe na tawe $\left[\mathrm{V}+\mathrm{NP}^{\mathrm{acc}}(\right.$ coffee $)+$ Prep (direction on $)+\mathrm{NP}^{\mathrm{acc}}$ (the coffee table)].

kawa na tawe $\left[\mathrm{NP}^{\mathrm{nom}}\right.$ (coffee) Prep (direction on) $+\mathrm{NP}^{\mathrm{acc}}$ (the coffee table) $]$

The verb component of the former is realised as wykładać/wytozyc 'put, lay' imperf/perf, być 'be', less commonly as wygarnać 'take out, rake out', mówić 'say', wyjaśniać 'explain'; rarely walić 'chuck, throw', wywalać 'chuck out'. The change in the verb component does not bring about a change of denotation. Altogether, these realisations form a variation series ( $\mathrm{Pl}$ 'szereg wariacyjny') differing only in expressive and stylistic meaning (Lewicki 2003: 249-250).

The latter form, an independent phrase kawa na tawe, is a case of syntactic phraseological derivation, to use Lewicki's (2003) terminology: an expressive nominalisation of the idiom, in which the verbal element is reduced and the nominal element adopts the nominative case. In this version, the idiom can function as an imperative: Kawa na tawe!! [Coffee on the coffee table!] or it can take the position of an embedded sentence: Jak powoli $i$ doktadnie, kawa na tawę, wyjawit wszystkie powiqzania Jurka ze światem przestępczym. [As he re- 
vealed slowly and in detail, "coffee on the coffee table", all Jurek's relations with the underworld] (Lewicki 2003: 224-225).

The idiom sometimes appears in the causative form mieć coś wytożone (jak) kawa na tawe [have sth V-past participle + prep (like) $+\mathrm{NP}^{\text {nom }}$ (coffee) Prep (direction on) $+\mathrm{NP}^{\text {acc }}$ (the coffee table)]:

58) ... czyli my mamy to wszystko mieć wyłożone jak kawa na ławę...

$(N K J P)$.

[... that is, we must have everything "laid like coffee on the coffee table"...]

59) ... [B]yło łatwiej, bo naprawdę miał już wyłożone, jak to się mówi: kawa na ławę...

[... [I] t was easier, because he really had it already, as they say, "laid: coffee on the coffee table"...]

Passive constructions are also possible, as the examples in NKJP illustrate: wszystko wywalone jak kawa na lawe 'everything "chucked out like coffee on the coffee table", jest jak kawa na tawe napisane 'it's written "like coffee on the coffee table", bo jest tzw. gola prawda, wywalona niczym kawa na tawe "because there is the so-called naked truth, "chucked out like coffee on the coffee table"".

\subsubsection{Pragmatics}

stylistic properties:

According to PSF and SSJP, wyktadać kawe na ławe is "pot", i.e. colloquial. The occasional occurrence of the verb wywalic 'chuck out' enhances this stylistic effect, e.g. wszystko wywalone jak kawa na tawe 'everything "chucked out like coffee on the coffee table", nie można byto wywalać kawy na tawe "you could not "chuck out coffee on the coffee table", I tu wale jej kawe na tawe 'Here I am "chucking out coffee on the coffee table" for her' (NKJP). Aware of the stylistic marking of this idiom, speakers may even apologise for resorting to it in more formal situations.

60) Z tym, że prosimy: kawę na tawe (przepraszam za takie proste określenie)

[But please: "coffee on the coffee table" (excuse such a simple expression).]

the degree of familiarity and/or textual frequency: 
65 examples remained after irrelevant material from the original sample of 81 hits had been removed. In the sample, the sense 'to speak directly' was more frequent than 'to explain sth in simple terms' (only about 17\%).

the cultural component:

The phrase does not involve any culturally-specific knowledge.

illocutionary function:

When used to mean 'to explain sth in simple terms', the idiom implies condescension on the part of the speaker, a slightly patronising attitude towards the person for whom we "put coffee on the coffee table". In the sense "to speak openly, directly, bluntly', the phrase can express slight disapproval of the person who is not very tactful, e.g.

61) Bonifacy wyłożył swoje pouczenia brutalnie, kawa na ławe (NKJP). [Bonifacy gave his advice with brutal honesty, "coffee on the coffee table".]

The expression is often preceded by metalinguistic markers such as jak to sie mówi 'so to speak'. Occasionally, it is used in inverted commas, explicitly singled out as a special manner of speaking: metoda "kawe na tawe" "by the "coffee on the coffee table" method'.

\section{Discussion}

\section{1. not mince (one's) words vs. nie przebierać w stowach}

The actual meanings of both idioms involve the component of verbal aggression. The difference lies in the level of that aggression and in the resulting degree of perceived rudeness. The English idiom implies that the speaker does not bother to use euphemisms ("minced" words), so that neutral words are used where more delicate ones might be appropriate; the Polish expression stresses that, instead of neutral words, rude ones are used. The ultimate effect is, of course, the same: perceived tactlessness and, possibly, offence.

Both idioms include the lexical component words/stowa. Words are objectified, which makes it possible to handle them manually. Though in one case the mental image is that of the mincing of objects and in the other of choosing them carefully, both idioms hinge on not doing something because of disregard for another person's feelings, and both are motivated by the combination of the onto- 
logical metaphor IDEAS ARE THINGS and the structural conduit metaphor LINGUISTIC EXPRESSIONS ARE CONTAINERS FOR IDEAS. There are also syntactic analogies: the subject can be human or not; the patterns have a common element $[\mathrm{Neg}+\mathrm{V}+(\ldots)+\mathrm{N}]$. Neither idiom is subject to any special stylistic restrictions, and both can serve the purpose of pejorative evaluation in discourse. The implications of their opposite (but not exactly antonymous) forms are also similar: przebierać $w$ stowach 'to use excessively mild terms to express your opinion' corresponds to the sense present in mincing manner 'a prim manner, one of affected delicacy' (Brewer).

\section{2. not mince (one's) words vs. wytożyć kawę na tawe}

The idioms are equivalent only in the sense 'to speak openly or directly, bluntly; to say what you mean clearly and directly, even if this upsets someone'. Unlike the English idiom, the Polish expression does not carry any strong implication of verbal aggression. The lexical composition, and consequently, the rich images differ considerably. The characteristics of the image underlying wytożyć kawe na tawe may motivate the absence of a non-human Agent. The underlying conceptual metaphors are not parallel, either: KNOWING IS SEEING in the case of wytozyć kawe na tawe and IDEAS ARE FOOD for not mince (one's) words. The Polish idiom emphasizes openness, directness rather than bluntness, forcefulness. The syntactic patterns are divergent, and wyktadac kawe na tawe has a more colloquial ring to it. The illocutionary function of the overlapping senses is similar. The additional element of a slightly patronising attitude is absent in the English idiom. The almost identical corpus frequency cannot invalidate the evident incompatibility of the two alleged equivalents.

\section{3. not beat about the bush vs. nie owijać w bawetnę.}

Despite their divergent images, the idioms are semantically close. Superficially very different, the actions of circling a bush and of wrapping something in cotton share the circular movement. The two images evoke slightly different connotations: we circle the bush because we are afraid of scaring away whatever it hides; we wrap an object in cotton in order to hide it or to make it appear more acceptable on the outside. Beating about the bush entails more hesitation on the part of the speaker, caused by apprehension in approaching the subject, whereas "wrapping (sth) in cotton" seems to require more control and premeditation. Nonetheless, these are nuances of emotive meaning, so the actual meanings can be regarded as equivalent. Additionally, the syntactic patterns and combinatorial properties are the same. Although the Polish idiom may be slightly more informal than the English one, both carry a positive evaluation in discourse. 


\section{Conclusions}

The new systematic perspective on the contrastive analysis of idioms offered in Dobrovol'skij and Piirainen (2005) and applied in this paper can assist both bilingual lexicographers and translators in the selection of the most appropriate equivalents. As our small-scale sample analysis illustrates, contrasts in images will not always prevent idioms with similar actual meaning from being regarded as equivalents. Often, the more abstract level of conceptual metaphor becomes a crucial factor in taking decisions as to the ultimate equivalence of two expressions. Still, as Dobrovol'skij and Piirainen (2005: 71) warn, there is a chance that "in certain contexts the image component of the plane of content of a given idiom plays a crucial role in its functioning", for instance, restricting the semantic category of lexical items combining with the phrase. In sum, closeness of underlying imagery, as evident in the idioms discussed, does not guarantee identity with respect to all parameters of comparison (especially pragmatics). Only a microanalysis along the lines presented here can ascertain the degree of functional similarity between the candidates for equivalents.

Admittedly, this kind of fine-grained comparison may not be a realistic requirement for general-purpose dictionary projects, but it should feature as a crucial step in the compilation of bilingual dictionaries of idioms. Ideally, such dictionaries ought to include in their entries both TL paraphrases and idiomatic equivalents - provided, of course, that the latter can be identified, i.e. in cases such as those presented above.

\section{REFERENCES}

\section{DICTIONARIES}

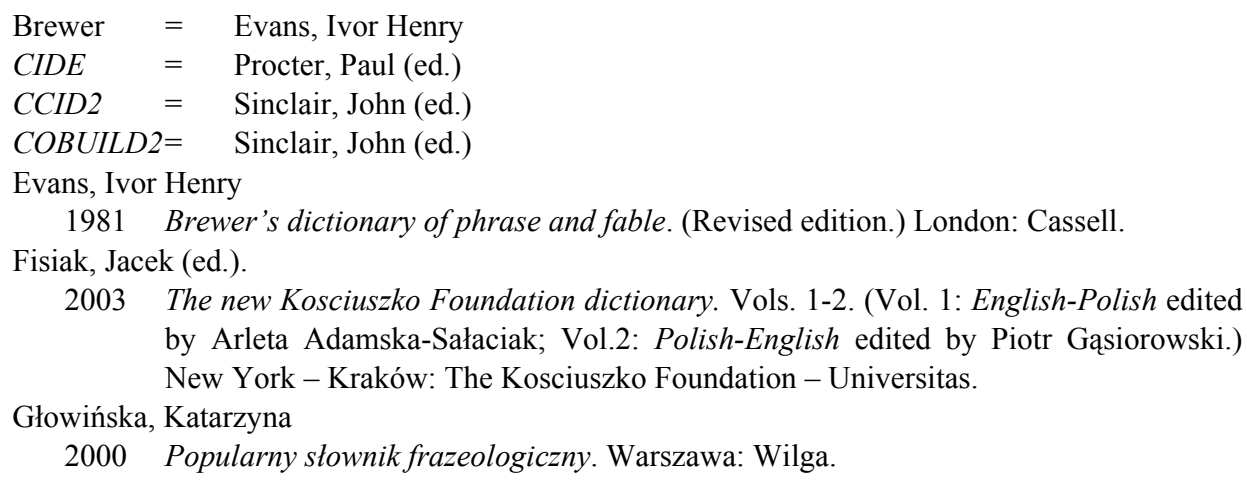


Holt, Alfred H.

1961 Phrase and word origins. (Revised edition.) New York: Dover Publications.

LDOCE3 = Summers, Della (ed.)

Linde-Usiekniewicz, Jadwiga (ed.)

2004 PWN-Oxford wielki słownik polsko-angielski. Warszawa: Państwowe Wydawnictwo Naukowe.

Müldner-Nieckowski, Piotr

2003 Wielki słownik frazeologiczny języka polskiego. Warszawa: Świat Książki.

NKFD $=$ Fisiak, Jacek (ed.)

Procter, Paul (ed.).

1995 Cambridge international dictionary of English. Cambridge: Cambridge University Press.

$P S F=$ Głowińska, Katarzyna

$P W N O P=$ Linde-Usiekniewicz, Jadwiga (ed.)

Sinclair, John (ed.)

1995 Collins COBUILD English dictionary. (2 ${ }^{\text {nd }}$ edition.) London: HarperCollins.

2002 Collins COBUILD idioms dictionary. (2 ${ }^{\text {nd }}$ edition.) Glasgow: HarperCollins.

SSJP = Szymczak, Mieczysław (ed.)

Summers, Della (ed.)

1995 Longman dictionary of contemporary English. ( $3^{\text {rd }}$ edition.) Harlow: Pearson Education Limited.

Szymczak, Mieczysław (ed.)

1978 Stownik języka polskiego. Vols. 1-3. Warszawa: PWN.

WSFJP = Müldner-Nieckowski, Piotr

\section{SECONDARY SOURCES}

\section{Adamska-Sałaciak, Arleta}

2006 Meaning and the bilingual dictionary: The case of English and Polish. Frankfurt/Main: Peter Lang Verlag.

Béjoint, Henri - Philippe Thoiron (eds.)

1996 Les dictionnaires bilingues. Louvain-la-Neuve: Aupelf-Uref-Éditions Duculot.

Gottlieb, Henrik - Jens Erik Mogensen (eds.)

2007 Dictionary visions, research and practice. Amsterdam - Philadelphia: John Benjamins.

Dobrovol'skij, Dmitrij - Elisabeth Piirainen

2005 Figurative language: Cross-cultural and cross-linguistic perspectives. Amsterdam: Elsevier.

Farø, Ken

2007 "Idiomatische Äquivalenzprobleme: Ein ikonoklastischer Zugang", in: Henrik Gottlieb - Jens Erik Mogensen (eds.), 83-95.

\section{Kövecses, Zoltán}

2002 Metaphor: A practical introduction. Oxford: Oxford University Press.

Krzeszowski, Tomasz Paweł

1997 Angels and devils in hell: Elements of axiology in semantics. Warszawa: Wydawnictwo Energeia. 
Lewicki, Andrzej Maria

2003 Studia $z$ teorii frazeologii [Studies in the theory of phraseology]. Lask: Oficyna Wydawnicza LEKSEM.

Mellado Blanco, Carmen

2009 Theorie und Praxis der idiomatischen Wörterbücher. (Lexicographica Series Maior 135.) Tübingen: Niemeyer Verlag.

Ortony, Andrew (ed.)

1979 Metaphor and thought. Cambridge: Cambridge University Press.

Reddy, Michael

1979 "The conduit metaphor: A Case of frame conflict in our language about language", in: Andrew Ortony (ed.), 284-297.

Roberts, Roda P.

1996 "Le traitement des collocations et des expressions idiomatiques dans les dictionnaires bilingues”, in: Henri Béjoint - Philippe Thoiron (eds.), 181-197.

Svensén, Bo

1987 Practical lexicography: Principles and methods of dictionary making. (Translated by J. Sykes and K. Schofield.) Oxford: Oxford University Press. [1993]

Zgusta, Ladislav

1971 Manual of lexicography. Prague: Academia. The Hague - Paris: Mouton. 